Araştırma Makalesi / Research Article

\title{
Relationship between futures contracts and macroeconomic variables: viop30 and dollar futures contracts application*
}

\section{Vadeli işlem sözleşmeleri ile makroekonomik değişkenler arasındaki ilişki: viop30 ve dolar vadeli işlem sözleşmeleri uygulaması}

Gönderim Tarihi / Received : 05.11.2020

Kabul Tarihi / Accepted : :08.01.2021

Doi: https://doi.org/10.31795/baunsobed.806135

\section{Yasemin KARATAŞ ELÇIÇEK"*1 Koray KAYALIDERE}

\begin{abstract}
As a result of the fluctuations in financial markets and an increase of uncertainties in markets, the investors are obliged to make effective risk management. Due to this obligation, one of the methods preferred by investors in managing their risks has been to perform their transactions in futures markets. In this context, the aim of the study is to determine the macroeconomic dynamics that affect the VIOP30 and Dollar futures contracts traded in the Futures and Options Market in January 2013 and December 2017, based on return and volatility. For this purpose, monthly frequency data of 11 macroeconomic variables, which are frequently used in the related literature and expected to affect return and volatility, were used. In the study, the relationship between variables was examined by the ARDL bounds testing method. In the results of the study, while there were statistically significant results in the short and long term between some macroeconomic variables and the futures contract returns and volatility in question, no significant results were obtained with some variables. It is thought that the findings will contribute to the related literature.
\end{abstract}

Keywords: Future contracts, ARDL bounds testing, Return, Volatility.

ÖZ: Finansal piyasalarda yaşanan dalgalanmaların ve piyasalardaki belirsizliklerin artması neticesinde yatırımcıların etkin bir risk yönetimi yapma zorunluluğu meydana gelmiştir. Meydana gelen bu zorunluluk nedeniyle yatırımciların risklerini yönetmede tercih ettikleri yöntemlerden birisi de işlemlerini vadeli işlem piyasalarında gerçekleştirmek olmuştur.

\footnotetext{
"This study is part of a dissertation completed by Yasemin KARATAŞ ELÇIÇEK under the consultancy of Assoc. Dr. Koray KAYALIDERE in Manisa Celal Bayar University Institute of Social Sciences Department of Business Administration-Accounting Finance Program.

${ }^{*}$ Sorumlu Yazar / Corresponding Author

${ }^{1}$ Dr., Siirt University, Vocational School of Social Sciences, yaseminkarataselcicek@gmail.com, https://orcid.org/0000-0001-7423-5839

${ }^{2}$ Assoc. Prof. Dr., Manisa Celal Bayar University, Faculty of Economics and Administrative Sciences, koray.kayalidere@cbu.edu.tr, https://orcid.org/0000-0003-4073-1644
} 
Bu bağlamda çalışmanın amacı Ocak2013-Aralık2017 döneminde Vadeli Işlem ve Opsiyon Piyasasında işlem gören VIOP30 ve Dolar vadeli işlem sözleşmelerini getiri ve volatilite bazında etkileyen makroekonomik dinamiklerin belirlenmesidir. Bu amaç doğrultusunda ilgili literatürde de sıklıkla kullanılan, getiri ve volatiliteye etki etmesi beklenen 11 makroekonomik değişkenin aylık frekansta verileri kullanılmıştır. Çalışmada değişkenler arasındaki ilişki ARDL sınır testi yöntemiyle incelenmiştir. Çalışmanın sonuçlarında bazı makroekonomik değişkenler ile söz konusu vadeli işlem sözleşme getiri ve volatiliteleri arasında kısa ve uzun dönemde istatistiksel olarak anlamlı sonuçlar bulgulanırken, bazı değişkenlerle anlamlı sonuçlar elde edilememiştir. Elde edilen bulguların ilgili literatüre katkıda bulunacağı düşünülmektedir.

Anahtar Kelimeler: Vadeli işlem sözleşmeleri, ARDL sınır testi, Getiri, Volatilite. 


\section{GENIŞLETILMIŞ ÖZET}

\section{Literatür taraması}

Vadeli işlem (futures) sözleşmeleri, önceden belirlenen nitelik, miktar ve fiyattaki malı ya da finansal enstrümanı gelecekteki bir tarihte teslim etme veya teslim alma yükümlülüğ̈̈ veren yasal finansal araçlardır (Molva, 2008). Vadeli işlem piyasaları, sözleşmeye konu olan ürünün fiyatında gelecekte meydana gelebilecek olumsuz değişimlere karşı yatırımcıya korunma imkânı sunmaktadır. Bunun yanında aynı nitelikteki varlıkların fiyat farklılıklarından faydalanılarak ilgili varlığın fiyatının ucuz olduğu piyasadan alınıp fiyatının pahalı olduğu piyasada satılması suretiyle risksiz kazanç sağlamalarına olanak vermektedir.

\section{Yöntem}

Çalışmada ARDL (Auto Regressive Distrubuted Lag Models) analizi yöntemi kullanılmıştır. ARDL sınır testi analizi uygulanırken öncelikle uygun gecikme uzunlukları test edilmiş ve uygun model belirlenmiş, sonrasında eşbütünleşme analizi yapılmış ve eşbütünleşme ilişkisinin varlığ 1 halinde ise sırasıyla uzun ve kısa dönem elastikiyetleri elde edilmiştir.

\section{Bulgular ve tartışma}

Çalışmadan elde edilen ARDL sınır testi uzun dönem bulgularına göre, VİOP30 vadeli işlem sözleşme getirisi uzun dönemde BA/GSYİH, sanayi üretim endeksi, faiz, para arzı değişkenlerinden negatif, ihracat, ithalat ve enflasyon değişkenlerinden pozitif yönde etkilenmektedir. Dolar vadeli işlem sözleşme getirileri BA/GSYİH, para arzı ve VIX endeksinden pozitif yönde, ithalat değişkeninden ise negatif yönde etkilenmektedir.

VİOP30 vadeli işlem sözleşme volatilitesi uzun dönemde, BA/GSYİH ve enflasyon değişkenlerinden pozitif, CA/GSYİH ve petrol değişkenlerinden negatif yönde etkilenmektedir. Dolar vadeli işlem sözleşme volatilitesi uzun dönemde, BA/GSYİH, sanayi üretim endeksi, faiz, altın ve enflasyon değişkenlerinden pozitif, CA/GSYİH ve ithalat değişkeninden ise negatif yönde etkilenmektedir.

ARDL sınır testi kısa dönem sonuçlarına göre, VIOP30 vadeli işlem sözleşme getirisi altın, ithalat, petrol ve enflasyon değişkenlerinden pozitif, BA/GSYİH, sanayi üretim endeksi, faiz ve VIX endeksi değişkenlerinden negatif; Dolar vadeli işlem sözleşme getirisi enflasyondan pozitif, CA/GSYİH ve ithalat değişkenlerinden negatif yönde etkilenmektedir.

VİOP30 vadeli işlem sözleşme volatilitesi kısa dönemde, BA/GSYİH, sanayi üretim endeksi ve faiz değişkenlerinden pozitif; Dolar vadeli işlem sözleşme volatilitesi BA/GSYİH, sanayi üretim endeksi değişkenlerinden pozitif, altın ve VIX endeksi değişkenlerinden ise negatif yönde etkilenmektedir. 
Literatür incelendiğinde sanayi üretim endeksi ve para arzı ile hisse senedi getirileri arasında genellikle pozitif bir ilişki olduğu gözlemlenmektedir. Çalışmada ise literatürden farklı bir sonuç elde edilmiştir. Hisse senedi getirilerini etkileyen pek çok faktör bulunmaktadır. Sanayi üretim endeksi bu faktörlerden bir tanesidir. Dolayısıyla bu durumun incelenen dönemdeki yatırımcıların yatırım kararlarını verirken sanayi üretim endeksi verilerini göz önünde bulundurmadığından kaynaklandığı düşünülmektedir. Para arzındaki artışların hisse senedi getirilerini artırdığına yönelik bulgulara karşın Zügül ve Şahin (2009) çalışmalarında para arzı ile hisse senetleri fiyatları arasında negatif ilişki bulgulamışlardır. Çalışmamızın sonucu bu açıdan söz konusu çalışmayla benzerlik göstermektedir. Alternatif bir yatırım aracı olması nedeniyle faiz oranlarının artmasının hisse senedi fiyatı üzerinde yapacağı olumsuz etkiden dolayı hisse senedi getirileri ile faiz arasında beklenildiği gibi negatif ilişki bulgulanmıştır. Aktaş ve Akdağ (2013) çalışmalarında ihracatın sanayileşmiş ve sanayileşmekte olan ülkelerin ekonomik gelişmişlik göstergelerinden biri olarak değerlendirilebileceği ve ihracat fazlasına sahip bir ekonominin sağlıklı bir ekonomik sistemin göstergesi olduğu ifade edilmiştir. Bu açıdan değerlendirildiğinde ihracatın fazla olmasının yatırımcılar açısından olumlu değerlendirileceği ve bu durumun da hisse senedi fiyatlarına olumlu yansımasından dolayı pozitif ilişki elde edildiği düşünülmektedir. Enflasyon ile hisse senedi getirileri arasındaki ilişki konusunda literatürde tam bir görüş birliği mevcut değildir. Enflasyonun hisse senedi fiyatlarını negatif yönde etkilediğini ifade edenlerin yanı sıra pozitif olarak etkilediğini ifade edenler de olmuştur. Al-Khazali (2003) çalışmasındaki uzun dönem bulguları, beklenen enflasyon ve beklenen enflasyondaki artışla hisse senedi fiyatları arasında hisse senetlerinin enflasyondan korunma aracı olarak algılanmasından kaynaklanan pozitif yönde bir ilişki içeren Fisher etkisini destekler niteliktedir. Çalışmadan elde edilen sonuç bu açıdan söz konusu ifadeyle aynı doğrultuda çıkmıştır. Diğer bir ifadeyle hisse senetlerinin enflasyondan korunma aracı olarak alg1lanmasından dolayı VIOP 30 getirileri ile enflasyon arasında pozitif ilişki çıktığ1 düşünülmektedir. VIX endeksinin yükselmesi yatırımcıların risk algısının yükseldiğini ve geleceğe yönelik beklentilerinin kötüleştiğini ifade ederken; VIX endeksinin azalması yatırımcıların risk algısının azaldığını ve geleceğe daha iyimser baktıklarını ifade etmektedir. Dolayısıyla VIX endeksi ile hisse senedi getirileri arasındaki ilişkinin negatif çıkmasının bu durumdan kaynaklandığı düşünülmektedir.

Para arzının döviz kuru üzerindeki etkisini monetarist yaklaşım iki açıdan değerlendirmiştir. Birincisi kısa dönemde para arzındaki artışlar faizleri düşürür ve bu durum ulusal para cinsinden aktiflerin getirisini azaltır. İkinci olarak ise uzun dönemde para arzındaki artışlar fiyatlar genel düzeyini artıra- 
cak satın alma gücü paritesine göre döviz kurunu artıracak ve ulusal paranın değerini düşürecektir. Bunun yanında Türkiye'deki fiyatlar genel düzeyindeki artışlar döviz kurunun beklenen değerini artıracağı için yabancı aktiflerin getirisini de artıracaktır (Yalta, 2011).

\section{Sonuç ve öneriler}

Yapılan analiz sonuçlarına göre bazı makroekonomik göstergelerin incelenen vadeli işlem sözleşmeleri üzerinde etkili olduğu bazı değişkenlerin ise anlamlı bir etkiye sahip olmadığı bulgulanmıştır. Çalışmadan elde edilen bu bulgular risklerini minimize etmek isteyen hedgerler, kazanç sağlamak isteyen spekülatör ve arbitrajcılar açısından önem arz etmektedir. Yatırımcıların yatırım yapmak istedikleri finansal enstrümanın fiyat seviyesinde meydana gelebilecek değişimin sinyalini alabilmelerine yardımcı olabileceği öngörülmektedir Diğer bir ifadeyle piyasa aktörleri makroekonomik ve finansal bilgiler yardımıyla risklerini yönetebilir ve getirilerini artırabilir. Ayrıca çalışmanın literatüre de katkı sağlayacağı düşünülmektedir.

Yapılacak olan çalışmalarda, incelenen vadeli işlem sözleşme türü ya da makroekonomik faktör artırılarak, analiz dönemi ve kullanılan yöntem değiştirilerek analiz tekrarlanabilir. Ayrıca opsiyon sözleşmeleri için de benzer modeller kullanılarak karşılaştırma yapılabilir. 


\section{Introduction}

The emerging developments in financial markets have also brought an increase in the risks that may be encountered in these markets. Therefore, it is of great importance for market traders to be able to manage these risks effectively. One of the preferences of investors who want to be protected against risks or effectively manage risks is futures contracts.

Futures markets offer investors the opportunity to protect themselves against negative future changes in the price of the contract product. In addition, future markets enable them to obtain risk-free earnings by purchasing them from the market where the price of the related asset is cheap and selling it in the market where the price is expensive by making use of the price differences of the assets of the same nature,. Advantages of the futures markets such as low transaction costs, high liquidity, and leverage make these markets more attractive for investors. Therefore, factors affecting contracts traded in these markets based on return and volatility are of great importance for investors. In this context, the purpose of the study is to analyse the relationship between VIOP30 and Dollar futures contract returns and volatility, and macroeconomic variables traded in the Futures and Options Market, using the ARDL analysis method. The national literature reveals that there are a limited number of studies examining the relationship between futures contracts and macroeconomic variables. This indicates that studies examining the relationship between futures contracts and macroeconomic variables should be conducted. However, the inclusion of a large number of macroeconomic variables in a single study and the period taken as basis being different may both differentiate the study from other studies in the literature and allow information users that benefit from the results of the study to make comparisons.

\section{Literature review}

Given the national and international literature on the relationship between futures contracts and macroeconomic variables, the national literature review reveals that studies on these issues are scarce and mostly focus on spot markets, while in the international literature, the relationship between macroeconomic news announcements and futures contracts is mainly discussed. Some studies examining the relationship between the spot market and futures contracts and macroeconomic variables that are similar to the purpose of the study are discussed in the next paragraph. The table summarizing the studies based on "The Surveyed Market, Contract Type, Country, Macroeconomic Variables, Period, and Method" has been included in the Appendix 1. 
Bhattacharya and Mukherjee (2002) state that there is a one-way causal relationship between the inflation variable and stocks, from the industrial production index to stock prices, and that there is no relationship between money supply, national income and interest rate, and stock prices. Cummings and Lee (2011) suggest that unlike other periods, during times of crisis the price volatility and volume are higher, the difference between the purchase and sale price is wider, the depth is less, the price volatility and transaction volume react more violently to macroeconomic news, the response is short-lived, and macroeconomic news contains rich information. They further suggest that in the crisis period subject to analysis, the price volatility increased three times per minute, the transaction volume and the price difference of purchase and sale doubled per minute, and the average depth decreased by half. It is also suggested that this period decreased to one minute in the crisis period when an increase in price volatility was observed to be up to ten minutes due to the reaction to macroeconomic information in the pre-crisis period with a similar situation observed in the transaction volume. It was stated that while the transaction volume increased in the first two minutes when the macroeconomic news was received, it decreased to its normal level, but this period was extended up to fifteen minutes in the pre-crisis period.

Tangjitprom (2011) suggests that the variables of interest rate and exchange rate can significantly explain stock returns in the regression analysis results and that according to the results of Granger causality analysis, only a few macroeconomic variables (unemployment, interest) can predict the future stock return; however, the stock return can predict most of the macroeconomic variables except for that of unemployment. He further suggests that according to the results of the variance decomposition technique, the interest rate is the most important macroeconomic variable in explaining the variance in stock returns; however, all macroeconomic variables can only explain a small variance in stock returns.

Bastianin et al. (2012) suggest that the T-Index is not very important in both univariate and multivariate models, that is, it is not related to the explanation of commodity returns in both univariate and multivariate models, except that it has a statistically significant and positive effect on changes in crude oil prices. Macroeconomic and financial factors are important on futures contract returns, in particular, while return on equity has a positive effect; exchange rates have a negative effect, and energy commodity futures contracts and agricultural commodity futures contracts have statistically significant expansions within and among their groups. Finally, they have found that after 2000, although there was evidence of a general and positive trend in the market depth of all energy products markets, the depth in the oil futures market decreased after 
the financial crisis (after 2008), that is, the oil futures market seemed more vulnerable to financial speculation. Osamwonyi and Evbayiro Osagie (2012) state that stock returns are negatively affected by the money supply in the short term, and are positively and statistically significantly affected by the exchange rate, while in the long term the deferred value of stock returns, inflation rate and gross domestic product variables affect stock returns positively and statistically significantly.

Özgümüş et al. (2013) point out that ISE 100 futures contract returns traded in VOB (Futures and Options Market) are positively affected by the S\&P 500 return and negatively affected by gold prices and inflation; that ISE 100 futures contract volume is positively affected by the money supply and negatively affected by inflation and; that ISE 100 futures contract volatility is positively affected by gold prices and interest rate and is negatively affected by imports. They also add that ISE 30 futures contract return series are positively affected by the S\&P 500 and are negatively affected by gold prices and CA/GDP; that ISE 30 futures contract volume is positively affected by exports and is negatively affected by inflation and; that ISE 30 futures contract volatility is positively affected by gold prices and CA/GDP and is negatively affected by the S\&P 500. They also have found that dollar futures contract returns are positively affected by gold prices and are negatively affected by the S\&P 500 and that the dollar futures contract volume is positively affected by CA/GDP and gold, and the dollar futures contract volatility is negatively affected by imports and the S\&P 500. The Euro futures contract return is positively affected by gold and is negatively affected by the economic growth; the Euro futures contract volume is positively affected by gold prices, the S\&P 500, and money supply; and the Euro futures contract volatility is positively affected by inflation and gold prices and is negatively affected by imports. Ilgun et al. (2014) state that rises in inflation and budget deficit increase the real exchange rate and inflation affects the real exchange rate at a high level.

Chia and Lim (2015) state that stock prices are positively affected by money supply and interest rates and are negatively affected by inflation in the long term. It has also been indicated in the results that there is causality from monetary expansion and real interest rates to stock prices. Çetin-Demir (2015) has found that the BIST 30 index futures contract price affects the M2 money supply and S\&P 500 index positively and the risk premium negatively. Özdemir (2017) states that there is a causal relationship between the dollar futures contract, dollar rate, gold price, export amount, import amount, and industrial production index, while there is no causal relationship between the dollar futures contract and the interest rate and consumer price index variables. 
Sadeghzadeh and Elmas (2018) indicate that economic growth positively affects the average return of stocks both in the short term and in the long term; that increases in the industrial production index increase the returns of the stocks in the short term and decrease them in the long term and; that increases in inflation increase the stock returns in both the short term and the long term; however, the effect in the short term is higher and statistically significant. They have found that increases in the money supply reduce stock returns in the short term and in the long term and that increases in interest rates applied to time deposits by banks reduce the returns of stocks, especially in the short term. They further suggest that the increase in gold prices positively affects stock returns in the short term and the long term and that increases in exchange rates decrease stock returns in the short term and increase them in the long term. They have also found that the increases in the BIST100 index move the stock returns upwards in the short term, but this effect disappears in the long term and stock returns are determined according to different internal and external dynamics. They state that the 2001 and 2009 economic crises affected stock returns negatively in the short term and positively in the long term. They have found that increases in the fear index negatively affect stock returns both in the short term and in the long term, while consumer confidence affects the stock returns positively in the short term and negatively in the long term, and increases in CDS have a decreasing effect on stock returns both in the short term and the long term.

Syzdykova (2018) found in the results of the OLS analysis that the oil price and exchange rate negatively affect the stock prices. He states that in the cointegration analysis results, only the price of oil coincides with stock prices while in the results of causality analysis based on the error correction model, there is a one-way causality relationship from the oil price and industrial production index to the stock market. Şenol et al. (2018) state that historical share stock prices positively affect current share stock prices and that economic growth, active profitability ratio, current ratio, and leverage ratio have a positive effect on stock prices. Finally, they state that the interest rate of the Eurozone affects the stock prices negatively. Şit and Karadağ (2019) have found that the current account deficit, foreign trade deficit, the Central Bank's foreign exchange reserve, and CPI variables positively affect the exchange rate, while the interest rate negatively affects the exchange rate.

\section{Methodology}

\section{Scope of the study}

This study aims to examine the macroeconomic factors affecting the VIOP30 and Dollar futures contract returns and volatility. The analysis period of January 2013-December 2017 was determined for the study. The main reason 
for the analysis period start date to be set as January 2013 is the literature on futures markets. As it is known, futures markets are leveraged markets, and taking positions in markets is much cheaper than spot markets. Accordingly, a leverage hypothesis, which suggests that the price information flow will be from futures to spot markets, has been developed. On the other hand, considering the price formation of the asset in the markets or the precedence-succession relationship between the markets, it is known that theoretically, transportation and transaction cost hypotheses and an effective market hypothesis constitute critical bases. Kayalıdere et al. (2012) report that the dynamics in Turkish Futures Markets were the opposite of the dynamics in the world markets, especially in the pre-2010 period when the market was testing the formation of asset prices in markets and the precedence-succession relationship in markets. They came to the conclusion that the dynamics were normalized in the following period, for example, the precedence-succession relationship changed from the futures market to the spot market as expected. They attributed this result to the low transaction volumes in the market and thus to ineffectiveness. In this study, the post-2012 period when transaction volumes increased was taken into consideration in particular to reach meaningful findings.

In addition, the researcher intended to include share term transaction contracts in the analysis. As known, these contracts have started to be traded as of December 21, 2012. However, since no significant results were obtained in the analysis results, share term transaction contracts were not included in the study. The main reason is that the contracts have just started to be traded and thus have yet to reach a sufficient transaction volume. Future studies may focus on the investigation of macroeconomic effects on share term contracts with a subsequent analysis period taken as the basis for the research.

\section{Data set}

The tables below include dependent and macroeconomic variables that will be examined in the study.

Table 1: Dependent variables to be used in the study

\begin{tabular}{ll}
\hline $\mathbf{R}_{\text {VIOP30 }}$ & BIST30 futures contract monthly return \\
$\mathbf{R}_{\text {DOLAR }}$ & Dollar futures contract monthly return \\
$\mathbf{V}_{\text {VIOP30 }}$ & BIST30 futures contract monthly volatility \\
$\mathbf{V}_{\text {DOLAR }}$ & Dollar futures contract monthly volatility \\
\hline
\end{tabular}

Futures contracts that are the closest to maturity date are mainly preferred as they are the most traded and most liquid type of contracts (Andersson et al., 2006:13). For this reason, the contract in the nearest term was selected during 
the selection process of the contract for the dependent variables to be used in the study.

Table 2: Macroeconomic variables to be used in the study

\begin{tabular}{ll}
\hline BD/GDP $_{\mathrm{t}}$ & Ratio of budget deficit to GDP \\
IPI $_{\mathrm{t}}$ & Industrial production index $(2015=100)$ \\
CA/GDP & Ratio of current account deficit to GDP \\
CPI $_{t}$ & Consumer price index $(2003=100)$ \\
Interest $_{t}$ & CBRT overnight interest rate \\
Gold $_{t}$ & Return series calculated based on gold bullion prices \\
LExport $_{t}$ & Total exports on a monthly basis $(2010=100)$ \\
LImport $_{t}$ & Total imports on a monthly basis $(2010=100)$ \\
LMoney supply $_{t}$ & M2 money supply \\
Oil $_{t}$ & Brent Oil Prices \\
VIX $_{t}$ & Volatility Index (Fear Index) \\
\hline
\end{tabular}

Note: The sign " $\mathrm{L}$ " indicates that the natural logarithm of the variable is taken.

The data of the VIOP contracts used in the study were obtained from "datastore. borsaistanbul.com", the data about the VIX index from "www.tr.investing. com" and the data about the macroeconomic variables from "www.tuik.gov. $\operatorname{tr}^{\prime \prime}$ and "www.tcmb.gov.tr". The analysis was carried out using the "Eviews 10 " program.

Considering the variables in the study, it is seen that all the variables except GDP are in monthly frequency. Since the data must have the same frequency to perform the analysis, the GDP variable has been converted to the monthly frequency with the help of the cubic spline method which was previously used in the literature.

\section{Method}

The ARDL (Auto-Regressive Distributed Lag Models) analysis method was used in the study. Engle-Granger and Johansen tests are the tests that are frequently used in the literature to test the concept of co-integration, indicating that at least two non-stationary series have a stationary composition at their levels. In the relevant tests, the series, in which the co-integration relationship between them is examined, is required to be equally stationary. After the bounds testing approach was to the co-integration analysis which was developed by Pesaran and Pesaran (1997) and Pesaran et al. (2001), this is not a requirement anymore. Therefore, the method does not require the steady state of the series to be used in the analysis at the same level in choosing the ARDL bounds test approach 
as a method. For, while many variables used in the analysis are at a static level, the macroeconomic variables such as interest-imports-money supply have become static in the first-order differences. While applying the ARDL bounds testing analysis, firstly, the appropriate lag lengths were tested and the appropriate model was determined, secondly, the co-integration analysis was performed and in the presence of co-integration relationship, long and shortrun elasticities were obtained, respectively.

After selecting the appropriate model in the ARDL analysis, the co-integration analysis should be done. The F-test or Wald test can be used for this analysis. However, since F statistics are not standard, critical values calculated by Pesaran et al. (2001) should be used. These critical values consist of two parts, the first assuming that all variables are I (1), while the second assumes that all variables are I (0). In the interpretation of the F-Bounds test results, if the calculated F statistic is above the upper limit value I (1), there is a co-integration relationship, if the calculated F statistic is below the lower limit value I (0), there is no co-integration relationship. If the calculated F statistic is between the upper limit and the lower limit, it indicates that no interpretation can be made as to whether there is a co-integration relationship.

For the short-run relationship with the long-run ARDL models established in the study, error correction models based on ARDL have been arranged in the Append1x 2.

The "ECT" symbol seen in models (3) and (4) in Append1x 2 refers to the error correction term. This term indicates how much of the disequilibrium in the short run will stabilize in the long run. The error correction term is expected to be theoretically negative and statistically significant. The fact that the error correction term is equal to -1 indicates that all disequilibrium in the last period have disappeared, while the coefficient of this term between -1 and 0 indicates that only some of the disequilibrium in the last period have disappeared (Düzgün, 2010:236). The coefficient between -1 and -2 indicates that the error correction process reaches equilibrium by exhibiting decreasing fluctuations around long-run equilibrium values, whereas this coefficient being positive or smaller than -2 means that it has been moved away from the equilibrium (Alam and Quazi, 2003:97).

\section{Findings and discussion}

Since the variables examined in the study are time series, it is necessary to determine whether they are stationary or not, in other words, the degree of integration. Stability states of the variables in the study were examined using ADF, PP, KPSS unit root tests ${ }^{1}$.

\footnotetext{
${ }^{1}$ Stationarity analysis results are given in Appendix 1.
} 
In the ARDL model, it is primarily necessary to determine the appropriate lag length. In the study, the data are at the monthly frequency and lag lengths have been tried up to 3 lags. According to the Schwartz Bayesian Criteria (SBC), the appropriate lag was chosen. After selecting the appropriate lag length, the Breush-Godfrey Autocorrelation Test was used to test whether there is a problem of autocorrelation in the model, and the ARCH Test was used to test whether there is a different variance problem. Model stability tests (CUSUM Test and CUSUM of Squares Test) were also applied in the selection of the appropriate lag length and were not reported to avoid prolonging the study. In line with these results, the most appropriate lag lengths and models for the return and volatility series were determined.

Table 3: Determination of appropriate lag length and appropriate model for bounds testing

\begin{tabular}{lccccc}
\hline Lag & SIC & $\begin{array}{c}\text { Breush-Godfrey } \\
\text { Autocorrelation } \\
\text { Test } \\
\text { (Probability } \\
\text { Values) }\end{array}$ & $\begin{array}{c}\text { ARCH Test } \\
\text { Different } \\
\text { Variance Test } \\
\text { (Probability } \\
\text { Values) }\end{array}$ & $\begin{array}{c}\text { The Selected } \\
\text { Appropriate } \\
\text { Model }\end{array}$ \\
\hline $\begin{array}{l}\text { VIOP30 } \\
\text { Return }\end{array}$ & 1 & -2.48693 & 0.0000 & 0.0255 & \\
Analysis & 2 & -2.48693 & 0.0000 & 0.0255 & ARDL(3, 1, 1, 0, 3, \\
& 3 & -2.72778 & 0.1604 & 0.1972 & \\
Dollar & 1 & -4.28069 & 0.3199 & 0.7518 & ARDL $(1,2,0,0,1,3,3)$ \\
Return & 2 & -4.26665 & 0.3740 & 0.6505 & $0,0,0,1,0,0,3,0)$ \\
Analysis & 3 & -4.33480 & 0.2522 & 0.2595 & \\
& 1 & 0.74355 & 0.0710 & 0.7725 & ARDL $(1,2,2,0,2$, \\
VIOP30 & 2 & 0.61093 & 0.3485 & 0.2494 & $0,0,2,0,0,0,0)$ \\
Volatility & 3 & 0.63519 & 0.0461 & 0.9386 & \\
Analysis & 1 & 1.01654 & 0.6376 & 0.6550 & ARDL(2, 2, 3, 0, 0, \\
Dollar & 2 & 0.96381 & 0.4503 & 0.6419 & $1,0,0,0,0,0,3)$ \\
Volatility & 2 & 0.84223 & 0.0684 & 0.2323 & \\
Analysis & 3 & & & &
\end{tabular}

In Table 3, there are appropriate lag length selections for VIOP30 and Dollar futures contract returns and volatility and therefore, appropriate model selections and model validity tests. While determining the lag length, a problem occurred regarding the model stability in the return series of the dollar futures contract. This problem was solved by adding the dummy variable to the model, and the appropriate lag length and the appropriate model were determined after the problem was solved. No other problems were encountered while determining the appropriate lag length. 
Table 4: Co-integration results

\begin{tabular}{lcccc}
\hline & VIOP30 Return & Dollar Return & VIOP30 Volatility & Dollar Volatility \\
\hline $\mathrm{k}$ & 11 & 12 & 11 & 11 \\
F-ist & 14.5062 & 20.1945 & 9.4218 & 11.2049 \\
\hline
\end{tabular}

Note: \%1 lower limit: 2.41, \%1 upper limit: 3.61

\%5 lower limit: 1.98, \%5 upper limit: 3.04

The results in Table 4 highlight that the calculated F statistics are higher than the upper limit value; therefore, the existence of a co-integration relationship is possible.

\section{Findings of the contract return bounds testing}

First, the long-run and short-run results of the VIOP30 futures contract return bounds testing were addressed. After determining the long-run equilibrium relationship between the variables with the F Test, the parameters showing the long-run relationship were examined.

Table 5: Long-run results of viop30/return ardl $(3,1,1,0,3,2,2,2,0,3,3,3)$ model

\begin{tabular}{lcclcl}
\hline Variable & Coefficient & Prob. & Variable & Coefficient & Prob. \\
\hline BD/GDP & -2.5487 & 0.0195 & ALImport & 1.2888 & 0.0009 \\
IPI & -0.3384 & 0.0029 & ALMoney supply & -3.0594 & 0.0161 \\
CA/GDP & 1.5208 & 0.2459 & Oil & 0.1863 & 0.1009 \\
AInterest & -0.0629 & 0.0002 & CPI & 0.0397 & 0.0104 \\
Gold & -0.1041 & 0.5921 & VIX Index & 0.2524 & 0.1027 \\
LExport & 0.6496 & 0.0003 & C & -6.5536 & 0.0003 \\
\hline
\end{tabular}

According to the results in Table 5, the ratio of the increase in the budget deficit to the gross domestic product, the increase in IPI, $\Delta$ Interest, and $\Delta$ LMoney supply decrease the return on the VIOP30 futures contract in the long run while increases in Lexport, $\Delta$ limport, and inflation increase the return on VIOP30 futures in the long run. In addition, there was no statistically significant effect of the ratio of current account deficit to the gross domestic product, gold, oil, and VIX index variables on VIOP30 futures contract returns. There are studies in the literature to support these findings. Sadeghzadeh and Elmas (2018), Osamwonyi, and Evbayiro-Osagie (2012) can be examined for the direction and explanations of the relationship between the variables of IPI, money supply, and inflation, and stock returns. 
Table 6: Results of viop30/return ardl (3, 1, 1, 0, 3, 2, 2, 2, 0, 3, 3, 3) error correction model

\begin{tabular}{lcclcc}
\hline Variable & Coefficient & Prob. & Variable & Coefficient & Prob. \\
\hline BD/GDP & -1.8836 & 0.0000 & $\Delta$ LImport & 1.3769 & 0.0000 \\
IPI & -0.3415 & 0.0000 & Oil & 0.1960 & 0.0001 \\
Interest & -0.0656 & 0.0000 & CPI & 0.0266 & 0.0002 \\
Gold & 0.5201 & 0.0002 & VIX Index & -0.0588 & 0.0232 \\
LExport & 0.1268 & 0.3526 & CointEq(-1) & -1.6131 & 0.0000 \\
\hline
\end{tabular}

According to the information in the results in Table 6, the error correction coefficient was negative and statistically significant. This indicates that deviations occurring in the short run will approach the equilibrium value in the long run. According to Alam and Quazi (2003:97), if the error correction coefficient is between -1 and -2 , the error correction process reaches equilibrium by exhibiting decreasing fluctuations around long-run equilibrium values. Looking at the results related to the variables that examine the relationship in the short run, it is seen that the ratio of budget deficit to the gross domestic product, the variables of IPI, $\Delta$ interest, $\Delta$ Limport, gold, oil and CPI statistically affect the return on futures contracts of $1 \%$ and VIX index. While there is a short-run negative relationship between the ratio of "budget deficit to gross domestic product," the variables of IPI, $\triangle$ Interest and VIX Index, and return of VIOP30 futures contract, there is a positive relationship in the short run between gold, $\Delta$ LImport, oil and CPI variables, and VIOP30 futures contract returns. The Lexport variable had no statistically significant effect. There are findings in the literature to support the relationships between variables. Sadeghzadeh and Elmas (2018) can be examined for the direction and explanations of the relationships between inflation, interest, gold and VIX index variables, and stock returns.

The long and short-run results of ARDL related to dollar futures contract returns are set out in the tables below.

Table 7: Long-run results of dollar/return ardl $(1,2,0,0,1,0,0,0,1,0,0,3,0)$ model

\begin{tabular}{lcclcc}
\hline Variable & Coefficient & Prob. & Variable & Coefficient & Prob. \\
\hline BD/GDP & 1.3953 & 0.0011 & $\Delta$ LMoney supply & 5.7146 & 0.0000 \\
IPI & -0.0466 & 0.3401 & Oil & -0.0469 & 0.1451 \\
CA/GSYIH & 1.2208 & 0.2093 & CPI & 0.0017 & 0.8329 \\
$\Delta$ Interest & 0.0024 & 0.5857 & VIX Index & 0.0357 & 0.0852 \\
Gold & -0.0961 & 0.3397 & Dummy & 0.0091 & 0.3604 \\
LExport & 0.0573 & 0.5792 & C & -0.5858 & 0.5737 \\
$\Delta$ LImport & -0.8469 & 0.0027 & & & \\
\hline
\end{tabular}


According to the long-run model results of dollar futures contract returns, the ratio of budget deficit to the gross domestic product, increases in the $\Delta$ LMoney supply and VIX index increase the dollar futures contract return, while decreases in them decrease the dollar futures contract return. While increases in $\Delta$ LImport decrease the dollar futures contract return, decreases in $\Delta$ LImport increase the dollar futures contract return.

Table 8: Results of dollar/return ardl $(1,2,0,0,1,0,0,0,1,0,0,3,0)$ error correction model

\begin{tabular}{lcclcc}
\hline Variable & Coefficient & Prob. & Variable & Coefficient & Prob. \\
\hline CA/GDP & -3.0630 & 0.0001 & Dummy & -0.0170 & 0.0273 \\
$\Delta$ LImport & -0.3898 & 0.0000 & CointEq(-1) & -1.0173 & 0.0000 \\
CPI & 0.0098 & 0.0018 & & & \\
\hline
\end{tabular}

The error correction model results of the Dollar futures contract return shown in Table 8 highlight that the error correction coefficient for the model was statistically significant by taking a value between -1 and -2 . As mentioned earlier, if the error correction coefficient is between -1 and -2 , the error correction process reaches equilibrium by exhibiting decreasing fluctuations around long-run equilibrium values. According to the results regarding the variables, the ratio of the current account deficit to the gross domestic product and increases in $\Delta$ LImports have a decreasing effect on the dollar futures contract return, while decreases cause an increase in the dollar futures contract return. Increasing inflation increases dollar futures contract returns, while decreasing inflation decreases dollar futures contract returns. There are findings in the literature to support the relationships between variables. Şit and Karadağ (2019) can be examined for the direction and explanations of the relationship between the inflation variable and the exchange rate.

\section{Findings of the volatility bounds testing}

In this part of the study, macroeconomic variables affecting the volatility of VIOP30 and Dollar futures contracts traded in VIOP are tried to be determined and interpreted. For this purpose, the monthly return series has been created for futures contracts subject to analysis, but the conditional variance could not be detected in the monthly return series and therefore, GARCH-type models could not be estimated. Therefore, firstly, daily return volatility series were calculated by using daily return series, and then daily return volatility series were collected and converted to monthly frequency (Liu and Tse, 2013:4). Then, the effect of macroeconomic factors on volatility series converted to monthly frequency was investigated. 
Table 9: Results of garch $(1,1)$ model

\begin{tabular}{lll}
\hline & VIOP30 & DOLLAR \\
\hline & Mean Equation & \\
Constant & 0.000622 & $0.0004^{* *}$ \\
AR(1) & $0.8547^{* * *}$ & $-0.1908^{* * *}$ \\
AR(2) & $-0.9728^{* * *}$ & $-0.9918^{* * *}$ \\
MA(1) & $-0.8698^{* * *}$ & $0.1963^{* * *}$ \\
MA(2) & $0.9943^{* * *}$ & $0.9885^{* * *}$ \\
& Variance Equation & \\
Constant & $4.64 \mathrm{E}-06^{* * *}$ & $6.21 \mathrm{E}-07^{* * *}$ \\
$\alpha$ & $0.0364^{* * *}$ & $0.04560^{* * *}$ \\
$\beta$ & $0.9433^{* * *}$ & $0.9459^{* * *}$ \\
Log-lik & 3506.189 & 4397.853 \\
AIC & -5.5971 & -7.0237 \\
SIC & -5.5642 & -6.9909 \\
ARCH LM T $*($ R2 $)$ & 8.4016 & 3.9083 \\
P & 0.1354 & 0.5627 \\
Q(20) & $22.406[0.131]$ & $18.462[0.298]$ \\
$\mathrm{Q}_{s}(20)$ & $24.890[0.206]$ & $18.660[0.544]$ \\
\hline
\end{tabular}

Looking at the findings in Table 9, it is seen that the $\alpha$ and $\beta$ parameters are significant at a $1 \%$ significance level in all futures contracts. The condition for $\alpha+\beta<1$, which is necessary for the GARCH model, is also provided.

Table 10: Long-run results of viop30/volatility $\operatorname{ardl}(1,2,2,0,2,0,0,2,0,0,0$, 0) model

\begin{tabular}{lcclcc}
\hline Variable & Coefficient & Prob. & Variable & Coefficient & Prob. \\
\hline BD/GDP & 34.6893 & 0.0001 & ALImport & 3.4911 & 0.1839 \\
IPI & -1.1641 & 0.3082 & ALMoney supply & -3.4376 & 0.5582 \\
CA/GDP & -12.812 & 0.0999 & Oil & -0.6902 & 0.0240 \\
AInterest & -0.0639 & 0.3948 & CPI & 0.2021 & 0.0005 \\
Gold & 0.0100 & 0.9910 & VIX Index & -0.0991 & 0.5850 \\
LExport & 0.0459 & 0.9600 & C & -0.5301 & 0.9542 \\
\hline
\end{tabular}

According to the results in Table 10, while the ratio of budget deficit to the gross domestic product and inflation variables positively affect VIOP30 futures contract volatility in the long run, the ratio of current account deficit to the gross domestic product and oil variables have negative effects. In other words, the ratio of budget deficit to the gross domestic product and increases in inflation variables increase the VIOP30 futures contract volatility while decreases decrease the VIOP30 futures contract volatility. While the ratio 
of current account deficit to the gross domestic product and increases in oil variables decrease the VIOP30 futures contract volatility, decreases increase the VIOP30 futures contract volatility.

Table 11: Result of viop30/volatility $\operatorname{ardl}(1,2,2,0,2,0,0,2,0,0,0,0)$ error correction model

\begin{tabular}{lccccc}
\hline Variable & Coefficient & Prob. & Variable & Coefficient & Prob. \\
\hline BD/GDP & 11.0248 & 0.0000 & $\Delta$ Interest & 0.1174 & 0.0020 \\
IPI & 1.4071 & 0.0001 & CointEq(-1) & -1.2133 & 0.0000 \\
$\Delta$ LImport & -1.1101 & 0.1108 & & & \\
\hline
\end{tabular}

In the results shown in Table 11, the error correction coefficient was found to be statistically significant between -1 and -2 . This indicates that the error correction process reaches equilibrium by exhibiting decreasing fluctuations around long-run equilibrium values. In the short run, the VIOP30 futures contract volatility is positively affected by the ratio of "budget deficit to the gross domestic product and the variables of IPI and $\Delta$ Interest.

Table 12: Lon-run results of dollar/volatility ardl $(2,2,3,0,0,1,0,0,0,0,0,3)$ model

\begin{tabular}{lrrlrl}
\hline Variable & Coefficient & Prob. & Variable & Coefficient & Prob. \\
\hline BD/GDP & 23.0615 & 0.0112 & ALIImport & -3.9299 & 0.0065 \\
IPI & 5.9001 & 0.0014 & ALMoney supply & 4.8250 & 0.4757 \\
CA/GDP & -18.8256 & 0.0434 & Oil & -0.0058 & 0.9861 \\
SInterest & 0.1242 & 0.0234 & CPI & 0.1517 & 0.0096 \\
Gold & 2.3423 & 0.0779 & VIX Index & 0.4261 & 0.5091 \\
LExport & -1.2145 & 0.2058 & C & 12.0222 & 0.2135 \\
\hline
\end{tabular}

Table 12, in which the long-run results of the dollar futures contract volatility are analysed, highlights that the dollar futures contract volatility is positively affected by the ratio of the budget deficit of dollar futures contract volatility to the gross domestic product, IPI, $\Delta$ Interest, gold, and CPI variables while it is negatively affected by the ratio of current account deficit to the gross domestic product and the $\Delta$ LImport variable.

Table 13: Results of dollar/volatility $\operatorname{ardl}(2,2,3,0,0,1,0,0,0,0,0,3)$ error correction model

\begin{tabular}{lcclcc}
\hline Variable & Coefficient & Prob. & Variable & Coefficient & Prob. \\
\hline BD/GDP & 7.6006 & 0.0000 & VIX Index & -0.2735 & 0.0662 \\
IPI & 3.2439 & 0.0000 & CointEq(-1) & -1.2122 & 0.0000 \\
Gold & -1.2391 & 0.0483 & & & \\
\hline
\end{tabular}


The fact that the error correction coefficient of the model is between -1 and -2 and statistically significant indicates that the error correction process has reached equilibrium by displaying decreasing fluctuations around the long run equilibrium values. In the short run, the dollar futures contract volatility is positively affected by the ratio of budget deficit to gross domestic product and IPI variables and is negatively affected by gold and VIX index variables.

\section{Results and recommendations}

Fluctuations in asset prices and uncertainties in financial markets in the wake of globalization have increased. This situation requires investors to make effective risk management while making their investments. The transaction volume, which has increased continuously in futures markets especially since 2012, shows that investors are trying to trade in these markets to manage their risks. Therefore, determining the factors that affect the contracts traded in these markets based on the return and volatility is important for market professionals, theorists, investors who attempt to enter this market, and even for students who intend to get an education. In this context, the purpose of the study was determined as the investigation of the relationship between VIOP30 and Dollar futures contract returns and return volatility and macroeconomic variables traded in the Futures and Options Market in January 2013 and December 2017. The main reason for taking the research period from January 2013 as the start date is that the transaction volume in futures markets increased especially after 2012. In addition to the VIOP30 and Dollar series, at the beginning of the research, the researcher wanted to include share term transaction contracts, which have started to be traded as of the end of 2012 in the analysis. However, seeing that meaningful findings could not be reached in the series in question, they were excluded from the research. In addition, the fact that the ARDL bounds testing approach does not require the series in the analysis to be stationary at the same level played a decisive role in determining the method. For, while many variables used in the analysis are stationary, macroeconomic variables such as interest-import-money supply have become stationary in the first-order differences.

According to the long term findings of ARDL bounds testing, VIOP30 futures contract return is negatively affected by the variables of BD/GDP, industrial production index, interest, money supply and positively affected by export, import and inflation variables. Dollar futures contract returns are positively affected by the BD/GDP, money supply and VIX index, and negatively affected by the import variable.

In the long term, VIOP30 futures contract volatility is positively affected by BD/GDP and inflation variables, and negatively affected by CA/GDP and 
oil variables. In the long term, dollar futures contract volatility is positively affected by $\mathrm{BD} / \mathrm{GDP}$, industrial production index, interest, gold and inflation variables, and negatively affected by CA/GDP and import variables.

According to the short term results of ARDL bounds testing, VIOP30 futures contract return is positively affected by gold, import, oil and inflation variables, and negatively affected by BD/GDP, industrial production index, interest and VIX index variables; Dollar futures contract returns are positively affected by inflation and negatively affected by CA/GDP and import variables.

In the short term, VIOP30 futures contract volatility is positively affected by the variables of BA/GDP, industrial production index, and interest; Dollar futures contract volatility is positively affected by $\mathrm{BD} / \mathrm{GDP}$ and industrial production index variables and is negatively affected by gold and VIX index variables.

The literature review reveals that there is generally a positive relationship between the industrial production index, money supply and stock returns. In the study, a different result was obtained, which turns out to be different from those in the literature. There are many factors that affect stock returns, one of which is the industrial production index. Therefore, it is thought that this situation was due to the fact that investors did not take the industrial production index data into account while making their investment decisions. Despite the findings showing that increases in money supply lead to an increase in stock returns, Zügül and Şahin (2009) found a negative relationship between money supply and stock prices in their study. The result of our study is similar to that study in this respect. As expected, a negative relationship was found between stock returns and interest due to the negative effect that the increase in interest rates would have on the stock price, as it is an alternative investment tool.

Aktaş and Akdağ (2013:56) stated in their study that exports can be considered as one of the economic development indicators of industrialized and industrializing countries and that an economy with an export surplus is an indicator of a healthy economic system. When evaluated from this point of view, it is thought that the high amount of exports may be evaluated positively for investors and a positive relationship may be obtained due to the positive reflection of this situation on stock prices. There is no consensus in the literature on the relationship between inflation and stock returns. In addition to those who state that inflation negatively affects stock prices, there are also those who state that it has a positive effect. The long-term findings in the study of Al-Khazali (2003:310) support the Fisher effect, which includes a positive relationship between expected inflation and the increase in expected inflation and stock prices arising from the perception of stocks as a means of protection from inflation. The result obtained from the study is in line with 
the relevant statement in this respect. In other words, it is thought that there is a positive relationship between VIOP 30 returns and inflation, as stocks are perceived as a means of protection from inflation. While the increase in the VIX index indicates that the risk perception of investors has increased and their expectations for the future have deteriorated, the decrease in the VIX index indicates that the risk perception of investors has decreased and they are more optimistic about the future. Therefore, it is thought that the negative relationship between VIX index and stock returns is due to this situation.

The monetarist approach has evaluated the effect of money supply on exchange rate based on two perspectives. First, increases in money supply in the short run decrease interest rates reducing the return on assets in national currency. Secondly, increases in the money supply in the long run lead to an increase in the general level of prices, increase the exchange rate according to the purchasing power parity, and decrease the value of the national currency. Besides, as prices in Turkey will increase the expected value for the increase in the general level of the exchange rate, they will also improve the return on foreign assets (Yalta, 2011; 194).

According to the results of the analysis, it has been found that some macroeconomic indicators are effective on the analysed futures contracts and some variables do not have a significant effect. These findings are important for hedgers who want to minimize their risks as well as for speculators and arbitragists who want to gain profit. It is predicted that they may also help investors get the signal of the change that may occur in the price level of the financial instrument they want to invest. In other words, market actors can manage their risks and increase their returns with the help of macroeconomic and financial information. In addition, it is thought that the study will contribute to the literature.

In the studies to be carried out, the analysis can be repeated by increasing the type of futures contract or macroeconomic factor to be analysed, by changing the analysis period and the method used. Also, comparisons can be made using similar models for option contracts.

\section{References}

Aktaş, M. \& Akdağ, S. (2013). The research on the relation of economic factors and stock prices in Turkey, International Journal of Social Science Research, 2(1), 50-67.

Alam, I. \& R, Quazi. (2003). Determinants of capital flight: An econometric case study of Bangladesh. International Review of Applied Economics, 17(1), 85- 
103.

Al-Khazali, O. M (2003). Stock prices: Inflation and output evidence from the emerging markets. Journal of Emerging Market Finance, 2(3), 287-314.

Andersson, M., Sebestyén, S., \& Overby, L. J. (2009). Which news moves the euro area bond market? German economic review, 10(1), 1-31.

Bastianin, A., Manera, Ma., Nicolini, M. \& Vignati, I. (2012). Speculation, returns, volume and volatility in commodities futures markets. Review of Environment, Energy and Economics. 1(20), 1-11.

Çetin-Demir, G. (2015). Endeks vadeli işlem sözleşmelerini etkileyen makroekonomik faktörlerin analizi: Türkiye uygulaması. [Yüksek lisans tezi]. Marmara Üniversitesi.

Chia, R.C. J. \& Lim, S. Y. (2015). Malaysıan stock price and macroeconomic variables: Autoregressive distributed lag (ardl) bounds test. Kajian Malaysia: Journal of Malaysian Studies, 33(1), 85-103.

Cummings, J. R., \& Lee, E. Y. K. (2011). Response to public information in futures markets: Evidence from the financial crisi. SSRN, 1(1), 1-18.

Düzgün, R. (2010). Türkiye ekonomisinde para ve maliye politikalarinin etkinliği. Uluslararası Sosyal Araştırmalar Dergisi, 3(11), 230-237.

Ilgün, M. F., Dumrul, C. \& Aysu, A. (2014). Bütçe açıklarının reel döviz kuru üzerindeki etkileri: Türk ekonomisi üzerine bir uygulama. Uluslararası Yönetim Iktisat ve Işletme Dergisi, 10(23), 13-30.

Kayalıdere, K., Aracı, H., \& Aktaş, H. (2012). Interaction between derivatives and spot markets: An analysis on VOB. Muhasebe ve Finansman Dergisi, (56), 137-154.

Liu, S. \& Tse, Y. K. (2013). Estimation of monthly volatility: An empirical comparison of realized volatility, GARCH and ACD-ICV methods. Research Collection School of Economics, 1(1), 1-24.

Molva, P. (2008). Dövize dayalı vadeli işlem sözleşmesi ile kur riskinden korunmanın yolu ve korunma perfonmansı. [Yüksek lisans tezi]. Dokuz Eylül Üniversitesi.

Osamwonyi, I. O. \& Evbayiro-Osagie, E. I. (2012). The relationship between macroeconomic variables and stock market index in Nigeria. Journal of Economics, 3(1), 55-63.

Özgümüss, H., Korkmaz, T. \& Çevik, E. I.(2013). Makroekonomik faktörlerin vadeli işlem (futures) sözleşmelerine etkisi: VOB'ta bir uygulama. BDDK Bankacilık ve Finansal Piyasalar Dergisi. 7(1), 103-136. 
Pesaran, M. H., Shin, Y. \& Smith, R. J. (2001). Bounds testing approaches to the analysis of level relationships. Journal of Applied Econometrics, 16(3), 289-326.

Sadeghzadeh, K., \& Elmas, B. (2018). Makroekonomik faktörlerin hisse senedi getirilerine etkilerinin bist'de araştirilmasi. Muhasebe ve Finansman Dergisi, (80), 207-232.

Şenol, Z., Koç, S. \& Şenol, S. (2018). Hisse senetleri fiyatlarini etkileyen faktörlerin dinamik panel veri analiziyle incelenmesi. Gümüshane Üniversitesi Sosyal Bilimler Enstitüsü Elektronik Dergisi, 9(25), 119-135.

Şit, M., \& Karadağ, H. (2019). Döviz kurunu belirleyen ekonomik faktörler: Türkiye ekonomisi için ardl sinir testi uygulamasi. International Journal of Economic E Administrative Studies, (23), 151-168.

Syzdykova, A. (2018). Makroekonomik değişkenler ve hisse senedi piyasasi ilişkisi: KASE örneği. Çankırı Karatekin Üniversitesi IIBF Dergisi, 8(2), 331-354.

Tangjitprom, N. (2011). Macroeconomic factors of emerging stock market: The evidence from Thailand. International Journal of Financial Research, 3(2), 105-114.

Yalta, Y. (2011). Döviz Kurunun belirlenmesi. Türkiye Bilimler Akademisi, (13), 185-196.

Zügül, M. \& Şahin, C. (2009). IMKB 100 endeksi ile bazı makroekonomik değişkenler arasındaki ilişkiyi incelemeye yönelik bir uygulama. Akademik Bakış, 1(16), 1-16. 


\section{Appendix}

Appendix 1. Examples of studies in the related literature

\begin{tabular}{|c|c|c|c|c|c|c|}
\hline $\begin{array}{l}\text { Name of the } \\
\text { Researcher }\end{array}$ & $\begin{array}{l}\text { The Market/ } \\
\text { Type Subjec }\end{array}$ & $\begin{array}{l}\text { Contract } \\
\text { t to Analysis }\end{array}$ & $\underset{E}{E}$ & $\begin{array}{l}\text { Macroeconomic } \\
\text { Variables }\end{array}$ & $\begin{array}{l}\text { Period of } \\
\text { Analysis }\end{array}$ & Method \\
\hline $\begin{array}{l}\text { Bhattacharya } \\
\text { and } \\
\text { Mukherjee } \\
(2002)\end{array}$ & $\begin{array}{l}\text { Stock } \\
\text { Market }\end{array}$ & Price & 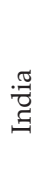 & $\begin{array}{l}\text { Money supply, IPI, } \\
\text { interest, domestic } \\
\text { income, inflation }\end{array}$ & $\begin{array}{l}\text { April1992 } \\
\text { March2001 }\end{array}$ & $\begin{array}{l}\text { Toda } \\
\text { Yamamoto }\end{array}$ \\
\hline $\begin{array}{l}\text { Cummings } \\
\text { and Lee } \\
(2011)\end{array}$ & $\begin{array}{l}\text { Index } \\
\text { Futures } \\
\text { Contract }\end{array}$ & $\begin{array}{l}\text { Price } \\
\text { Volatility } \\
\text { Volume } \\
\text { Difference } \\
\text { between } \\
\text { Buy-Sell } \\
\text { Prices }\end{array}$ & 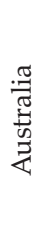 & $\begin{array}{l}\text { CPI, employment, } \\
\text { GDP, construction } \\
\text { licence, trade } \\
\text { balance, } \\
\text { inventories, } \\
\text { investment and } \\
\text { retail news }\end{array}$ & $\begin{array}{l}19 \text { December } \\
2003-18 \\
\text { December } 2008\end{array}$ & t-test \\
\hline $\begin{array}{l}\text { Tangjitprom } \\
\text { (2011) }\end{array}$ & $\begin{array}{l}\text { Stock } \\
\text { Market }\end{array}$ & Return & 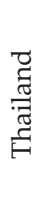 & $\begin{array}{l}\text { "Unemployment } \\
\text { rate, interest rate, } \\
\text { inflation rate and } \\
\text { exchange rate" }\end{array}$ & $\begin{array}{l}\text { January2001- } \\
\text { December2010 }\end{array}$ & $\begin{array}{l}\text { Regression, } \\
\text { vector auto- } \\
\text { regression } \\
\text { (VAR) and } \\
\text { Granger } \\
\text { causality }\end{array}$ \\
\hline $\begin{array}{l}\text { Bastianin et } \\
\text { al. (2012) }\end{array}$ & $\begin{array}{l}\text { Commodity } \\
\text { Futures } \\
\text { Contracts }\end{array}$ & Return & 岕 & $\begin{array}{l}\text { T-Bill rate, S\&P } 500 \\
\text { return, financial } \\
\text { distress index, } \\
\text { T-Index and } \\
\text { exchange rate }\end{array}$ & $1986-2010$ & $\begin{array}{l}\text { Regression, } \\
\text { GARCH and } \\
\text { MGARCH }\end{array}$ \\
\hline $\begin{array}{l}\text { Chia and } \\
\text { Lim (2015) }\end{array}$ & $\begin{array}{l}\text { Stock } \\
\text { Market }\end{array}$ & Return & 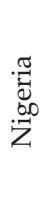 & $\begin{array}{l}\text { Interest rate, } \\
\text { inflation rate, } \\
\text { exchange rate, } \\
\text { financial deficit, } \\
\text { money supply and } \\
\text { GDP }\end{array}$ & $1975-2005$ & $\begin{array}{l}\text { Vector Error } \\
\text { Correction } \\
\text { Model } \\
\text { (VECM) }\end{array}$ \\
\hline $\begin{array}{l}\text { Özgümüşs et } \\
\text { al. (2013) }\end{array}$ & $\begin{array}{l}\text { Index and } \\
\text { Futures } \\
\text { Exchange } \\
\text { contracts }\end{array}$ & Volatility & $\underset{\vec{\Xi}}{\stackrel{\vec{a}}{\Xi}}$ & $\begin{array}{l}\text { Gold, Growth, } \\
\text { Budget Deficit/ } \\
\text { GDP, Current } \\
\text { Deficit/GDP, } \\
\text { inflation, interest, } \\
\text { export, import, } \\
\text { money supply and } \\
\text { S\&P } 500 \text { index }\end{array}$ & $\begin{array}{l}\text { February } 2005 \\
\text { - November } \\
2011\end{array}$ & $\begin{array}{l}\text { GARCH and } \\
\text { Regression }\end{array}$ \\
\hline $\begin{array}{l}\text { Ilgün et al. } \\
\text { (2014) }\end{array}$ & $\begin{array}{l}\text { Exchange } \\
\text { Market }\end{array}$ & $\begin{array}{l}\text { Real } \\
\text { exchange } \\
\text { rate }\end{array}$ & $\frac{\partial}{\vec{v}}$ & $\begin{array}{l}\text { Inflation and } \\
\text { budget deficit }\end{array}$ & $\begin{array}{l}\text { January } 1994 \\
\text { December } 2012\end{array}$ & ARDL \\
\hline $\begin{array}{l}\text { Chia and } \\
\text { Lim (2015) }\end{array}$ & $\begin{array}{l}\text { Stock } \\
\text { Market }\end{array}$ & Price & $\frac{\sqrt[\pi]{\pi}}{\sum_{\pi}^{\frac{\pi}{\pi}}}$ & $\begin{array}{l}\text { IPI, inflation, } \\
\text { money supply, } \\
\text { interest rate and } \\
\text { exchange rate }\end{array}$ & $1980-2011$ & ARDL \\
\hline
\end{tabular}


Relationship between futures contracts and macroeconomic variables: viop30 and dollar futures contracts application

Appendix 1 (More). Examples of studies in the related literature

\begin{tabular}{|c|c|c|c|c|c|c|}
\hline $\begin{array}{l}\text { Name of the } \\
\text { Researcher }\end{array}$ & \multicolumn{2}{|c|}{$\begin{array}{l}\text { The Market/Contract } \\
\text { Type Subject to Analysis }\end{array}$} & $\stackrel{\vec{E}}{\Xi}$ & $\begin{array}{l}\text { Macroeconomic } \\
\text { Variables }\end{array}$ & $\begin{array}{l}\text { Period of } \\
\text { Analysis }\end{array}$ & Method \\
\hline $\begin{array}{l}\text { Çetin-Demir } \\
(2015)\end{array}$ & $\begin{array}{l}\text { Index } \\
\text { Futures } \\
\text { Contract }\end{array}$ & Price & $\underset{\vec{d}}{\stackrel{\vec{\Xi}}{\Xi}}$ & $\begin{array}{l}\text { M2, inflation, GDP, } \\
\text { exchange rate, } \\
\text { current account } \\
\text { balance, market } \\
\text { interest rate, IPI, } \\
\text { S\&P 500, risk } \\
\text { premium and gold }\end{array}$ & $\begin{array}{c}2006 \text { Q1 - } \\
2014 \text { Q2 }\end{array}$ & Regression \\
\hline $\begin{array}{l}\text { Özdemir } \\
(2017)\end{array}$ & $\begin{array}{l}\text { Dollar } \\
\text { Futures } \\
\text { Contract }\end{array}$ & Return & 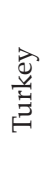 & $\begin{array}{l}\text { Exchange rate of } \\
\text { Dollar, export, } \\
\text { import, gold, } \\
\text { interest rate, IPI, } \\
\text { CPI }\end{array}$ & $\begin{array}{l}\text { January2005- } \\
\text { December2016 }\end{array}$ & $\begin{array}{l}\text { Granger } \\
\text { causality k } \\
\text { test }\end{array}$ \\
\hline $\begin{array}{l}\text { Sadeghzadeh } \\
\text { and Elmas } \\
(2018)\end{array}$ & $\begin{array}{l}\text { Stock } \\
\text { Market }\end{array}$ & Return & 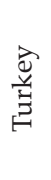 & $\begin{array}{l}26 \text { macroeconomic } \\
\text { variables and } 4 \\
\text { dummy variables } \\
\text { belonging to } 130 \\
\text { companies }\end{array}$ & $\begin{array}{l}\text { 2000:Q1- } \\
\text { 2017:Q3 }\end{array}$ & Panel ARDL \\
\hline $\begin{array}{l}\text { Syzdykova } \\
(2018)\end{array}$ & $\begin{array}{l}\text { Stock } \\
\text { Market }\end{array}$ & Price & 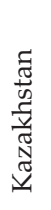 & $\begin{array}{l}\text { "Inflation rate, } \\
\text { interest rate, } \\
\text { exchange rate, } \\
\text { industrial } \\
\text { production index } \\
\text { and oil prices" }\end{array}$ & $\begin{array}{l}\text { Haziran2000 - } \\
\text { Nisan } 2017\end{array}$ & $\begin{array}{l}\text { EKK, } \\
\text { Johansen co- } \\
\text { integration } \\
\text { test and } \\
\text { Granger } \\
\text { causality }\end{array}$ \\
\hline $\begin{array}{l}\text { Şenol et al. } \\
\text { (2018) }\end{array}$ & $\begin{array}{l}\text { Stock } \\
\text { Market }\end{array}$ & Price & 离 & $\begin{array}{l}\text { Historical stock } \\
\text { prices, exchange } \\
\text { rate, growth rate, } \\
\text { interest rate, S\&P } \\
500 \text { stock index, } \\
\text { USA interest rate, } \\
\text { Euro interest rate, } \\
\text { return on assets, } \\
\text { stock turnover rate, } \\
\text { current rate and } \\
\text { leverage ratio. }\end{array}$ & $\begin{array}{l}\text { 2010Q1- } \\
\text { 2017Q1 }\end{array}$ & $\begin{array}{l}\text { Dynamic } \\
\text { panel data } \\
\text { set }\end{array}$ \\
\hline $\begin{array}{l}\text { Şit and } \\
\text { Karadağ } \\
(2019)\end{array}$ & $\begin{array}{l}\text { Exchange } \\
\text { Market }\end{array}$ & $\begin{array}{l}\text { Real } \\
\text { Exchange } \\
\text { Rate }\end{array}$ & 离 & $\begin{array}{l}\text { "BIST } 100 \text { index, } \\
\text { current account } \\
\text { deficit, foreign } \\
\text { trade deficit, } \\
\text { interest rate, money } \\
\text { supply, Central } \\
\text { Bank foreign } \\
\text { exchange reserves, } \\
\text { inflation" }\end{array}$ & $\begin{array}{l}\text { January2003- } \\
\text { June2018 }\end{array}$ & ARDL \\
\hline
\end{tabular}


Appendix 2. Ardl and error correction models

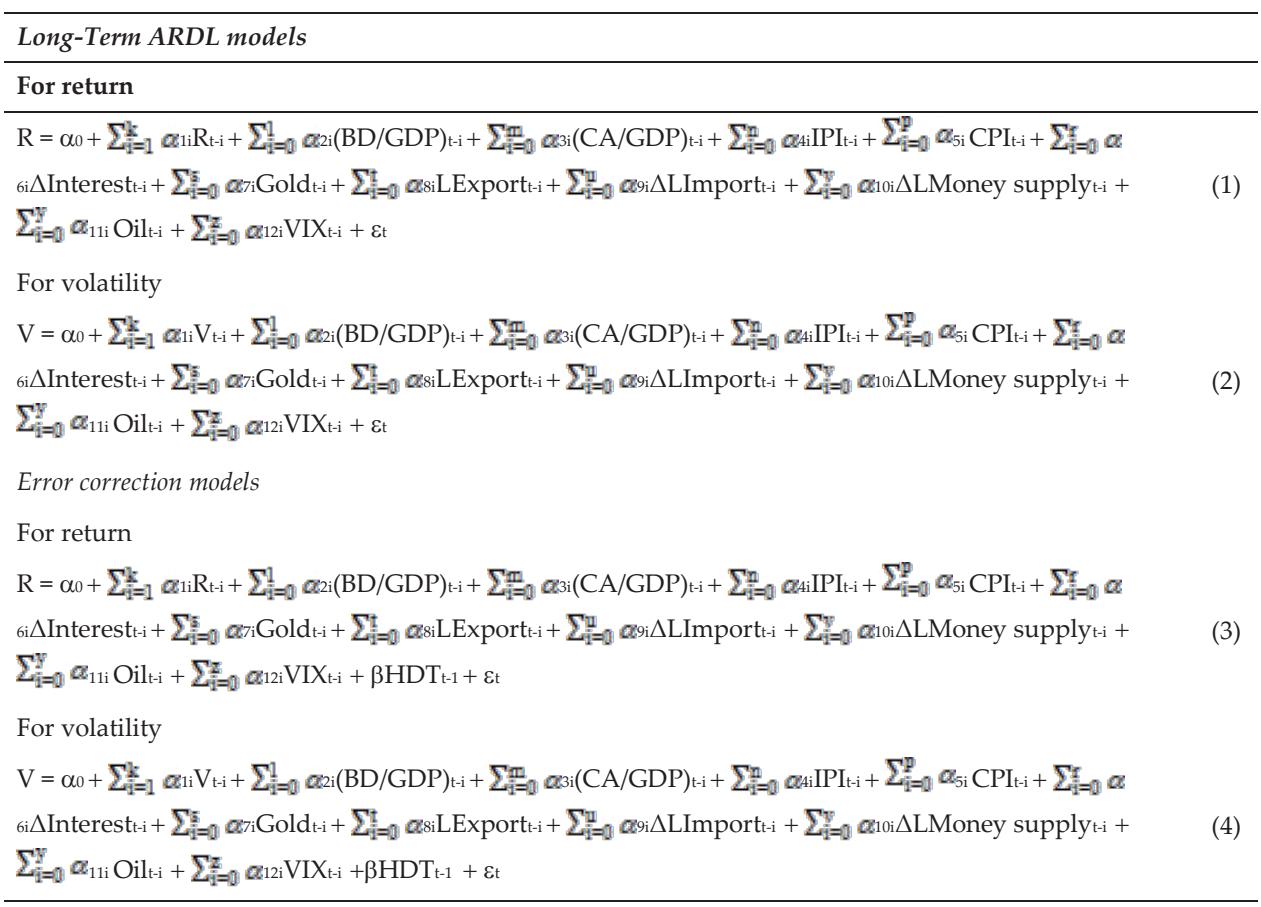

\section{Ethical Approval}

This study is among the studies that do not require ethics committee approval due to it is not a study conducted with qualitative or quantitative approaches that require data collection from participants using questionnaires, interviews, focus group work, observation, experimentation, and interview techniques.

\section{Contribution Rate of Researchers}

The authors contributed equally to the study.

\section{Conflict of Interest}

There is no potential conflict of interest in this study. 